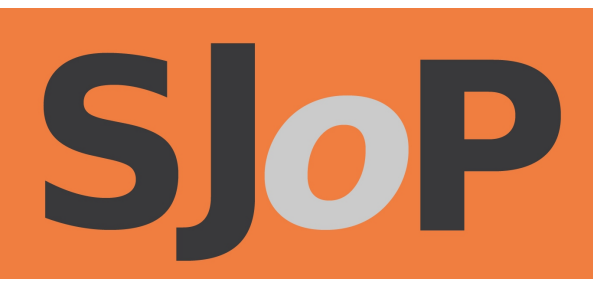

Book review: Men's cinema: masculinity and mise-en-scène in Hollywood, by Stella Bruzzi

\title{
ELISABETTA GIRELLI
}

The Scottish Journal of Performance

Volume 1, Issue 2; June 2014

ISSN: 2054-1953 (Print) / ISSN: 2054-1961 (Online)

Publication details: http://www.scottishjournalofperformance.org

To cite this article: Girelli, E., 2014. Book review: Men's cinema: masculinity and mise-en-scène in Hollywood, by Stella Bruzzi. Scottish Journal of Performance, 1(2): pp.107-110.

To link to this article: http://dx.doi.org/10.14439/sjop.2014.0102.07

(C) This work is licensed under a Creative Commons
Attribution 4.0 International License. See
http://creativecommons.org/licenses/by/4.0/ for details. 


\title{
Book review: Men's cinema: masculinity and mise-en-scène in Hollywood, by Stella Bruzzi
}

\author{
ELISABETTA GIRELLI
}

DOI: 10.14439/sjop.2014.0102.07

Publication date: 13 June 2014

Men's cinema: masculinity and mise-en-scène in Hollywood, by Stella Bruzzi. Edinburgh: Edinburgh University Press, 2013; ISBN 9780748676163 (£19.99)

Stella Bruzzi's new book makes a welcome intervention in the fields of film and gender studies. Skillfully building upon classic works on the construction of male identity on screen, she nevertheless provides a completely new focus on the topic, offering a valuable addition to existing scholarship on this most crucial issue.

The problem of how cinema organises and creates gendered images has long been at the forefront of film studies. However, as Bruzzi points out, the critical effort to deconstruct this gendering process has been dominated by relatively narrow theoretical and methodological prisms. Since Laura Mulvey's enormously influential essay Visual Pleasure and Narrative Cinema (1975), most approaches to the subject have been centered on the dynamics of the cinematic and spectatorial gaze, or more recently on the broader strategy of representation analysis. Indeed, the ubiquity of 'representation' as a key point of focus in the humanities has, to a large extent, precluded the opening up of different analytical avenues. It is in this context that Bruzzi's book makes its entry, proposing instead a bold shift: namely, a move away from representation and, even more 
specifically, from the critical insistence on the represented body that dominates past and current work in the field. This is not to say that the author is uninterested in the body as a crucial element in the articulation and experience of what she terms 'men's cinema': on the contrary, part of her argument is that films often convey masculinity through making the audience feel it at a visceral, thus corporeal, level. The process by which this effect is achieved is, according to her argument, inserted in the wider canvas of the films' aesthetics. The great novelty and value of Bruzzi's work is precisely here, in her focus on style and mise-enscène as vital components of cinematic masculinity.

Rather than just announce her different take on the topic, Bruzzi takes the reader through a comprehensive and critical review of masculinity scholarship, preparing the ground for her own intervention. Most interestingly, she shows how earlier criticism had already contained at least a hint of her own alternative view; for example, she quotes passages from the work of Thomas Elsaesser and Malte Hagener, identifying the semi-hidden possibilities in approaches to film criticism to which these earlier studies had alluded.

After this enlightening introduction, Bruzzi gets into the main body of her argument, ably supporting it with wellchosen and fascinating examples. Chapter 1, 'How Mise en Scène Tells the Man's Story', sets the scene by offering indepth textual analyses of Hollywood films spanning from the Classical era to the 1970s. Through case-studies ranging from To Kill a Mockingbird (1962) to The Deer Hunter (1978), the author convincingly shows how stylistic elements shape the screen's expression of masculinity. The book's next two chapters, 'Towards a Masculine Aesthetics' and 'Men's Cinema', bring her discussion up to the present via an impressively rigorous, eloquently assessed array of film deconstructions. The first of these two chapters 
concentrates on seminal films such as Once Upon a Time in the West (1968), The Wild Bunch (1969) and Dirty Harry (1971), which are approached as key and influential features in the development of more recent masculine aesthetics. The writing is eloquent and precise at the same time, and her close reading of, for instance, the crane shots in Once Upon a Time in the West is riveting. Bruzzi weaves camera movements, action or lack of it within the frame, and sound into a solid aesthetic formation which is both expressive of, and haunted by, the invocation of masculine worlds and narratives; yet she accomplishes this without privileging plot developments, devoting instead most of her critical attention to style. The result is eye-opening, thoroughly convincing, and critically exciting.

The final chapter continues the analysis of the stylistic elements responsible for the creation of masculine cinema through case studies that begin with Martin Scorsese's films of the 1980s and end with Inception (2010). Here again, Bruzzi reveals and sheds light on cinematic tropes and motifs which have been mostly ignored or taken for granted; I found her discussion of the men-walking-together image especially interesting. Throughout the book, she returns to the notion of an inclusive approach to 'men's cinema', making it absolutely clear that the aesthetics, effects and thrills described and analysed are not only enjoyable for men, thus further stressing the highly crafted nature of gender configurations.

The only possible query, or doubt, that this brilliant work provokes is really just an afterthought: could it be that 'representation' itself needs to be expanded as a term and as a practice? Do mise-en-scène, aesthetics, and all stylistic considerations truly occupy a separate realm of method and analysis? Or should the enquiry into a gendered mode of expression be seen as a multi-faceted enterprise that ultimately, indeed inevitably, deals with something the 
filmic image re-presents? On these possibly idle questions this review of Men's Cinema: Masculinity and Mise-enScène in Hollywood concludes, but not before stressing how this book will be indispensable to anyone studying or researching the presence of masculinity on screen. Through its challenging approach, its accessible and engaging writing style and its relevance to the discipline, Bruzzi's work is essential reading for university students at all levels, as well as for film and gender scholars.

\section{Reference}

Mulvey, L., 1975. Visual pleasure and narrative cinema. Screen, 16(3), pp.6-18. http://dx.doi.org/10.1093/screen/16.3.6

\section{About the review author}

DR ELISABETTA GIRELLI is a Lecturer in Film Studies at the University of St Andrews. Her research interests focus on the representation of identity, sexuality and gender, on film stars, on issues of bodily normativity, and on critical theory. Her latest book is a monograph entitled Montgomery Clift, Queer Star (Wayne State University Press, 2013), which provides an analysis of Clift's star persona and trajectory through the lens of queer theory. Previous publications include Beauty and the Beast: Italianness in British Cinema (Intellect, 2009), and various scholarly articles, most recently on subversion and spatial relationships in Czech cinema, and on representations of the Communist spy Guy Burgess in the light of nationality and notions of 'camp'. Elisabetta is currently working on a new project on silent film star Rudolph Valentino. 